\section{Phone A Friend, When In Need!}

A seemingly reserved person by appearance, I hardly ever won friends in life till the day I became a pediatrician. A secluded being till then, I was delighted to find new friends spring up each day. Old school mates to distant neighbours, unheard of cousins to friends of friends; people from all corners of the world, suddenly began to compete for my attention. The euphoria lasted only till I realized that the forced friendship was actually for my child-health knowledge and not exactly me!

Be it in the middle of the night or a Sunday afternoon, my new-found friends do not once hesitate to call me. Their love for me is so intense that they enquire in detail about my state of health, my morning breakfast and the evening weather before conveniently switching over to the topic of their child's stools which has recently changed frequency and consistency. Some old friends settled abroad, who had forgotten to even mention that they were moving out of country, suddenly miss me so much that they call on ISD, only to ask about the small boil on their baby's bum. The conversation for the next half an hour then flows from the bottom to the tummy with elaborate discussion on feeding and nutrition, ending with endless tips on parenting. Some of them consider it a combo offer and go on to ask about their mother-in-law's knee pain and uncle's hemorrhoids before hanging up.

At the end of each such friendly call, I feel conned for having been sweet-talked into losing my precious time and dispensing free medical advice. More than the money, its the interruption in my privacy and my flow of thoughts that disturbs me, for it takes a good 10 minutes to get back to my personal life, feeding my own child or planning my next meal.

If few of my new friends take the liberty of calling, few others go a step ahead and consider me as their personal log book. Right from the delivery of their baby, which forms the official initiation of our self-proclaimed friendship, they text me their baby's everyday events. From the volume of their baby's puke to the odour of his or her poo, I become the official record keeper. Most of the times, I also double up as a security guard on duty as any fit of cry by the newly arrived baby lands a distress call to me. While I take the pains for an hour and half to explain the causes of excessive cry in a newborn, the unconvinced mother ignores all the explanation and rushes to her pediatrician only to get back and annoyingly cross-check her family pediatrician's prescription with me. And then there are relatives who send pictures of the nappy rash or the running nose exactly when at dinner table, expecting miraculous overthe-phone, quick-fixes. And not to forget a few clever cousins who send reports of their friend's children only to test my knowledge of biochemistry and radiology. The next clan who consider themselves closest to me, barge directly into my house with their sick kids, faithfully lending all the viruses to my little girl, ensuring a forced holiday, till the virus limits itself.

Not just relatives and friends, even acquaintances appear to threaten me these days with their health queries. Be it birthday parties or holiday trips, I have realized that I earn new friends the moment I disclose my doctorly status, so much so that I have come to hide the fact that I am a doctor even from the medical representatives who want to visit me.

While I am yet to master the art of dispensing quick advice, I have, to some extent, learnt to avoid receiving calls. But my new friends are so persevering that they continue to call till I receive it or ping me, politely asking me to call back. While the blue ticks on whats App unfortunately reveal that I have read the message, I am often compelled to reply and sacrifice the next few minutes assuring a distressed mother about nasal block or transitional stools. Some days I feel more like a freely downloadable pediatric mobile app, than a humble human being. And on most other days I feel like a call centre employee working honorarily. Not that a payment for my advice would make it any more tolerable but at-least I wouldn't feel like a robbed credit card which is being swiped repeatedly before it is blocked.

I no doubt agree that it is easier and more comfortable to ask for professional health advice from friends as I myself indulge in all these histrionics with my own friends in varied specialities. But opportunistically making friends for benefits or taking friendliness for granted makes me feel like a chewed up piece of gum.

After all the wholesome cribbing, I feel a little lighter with the load off my heart. And I realize that deep within that heart, there lies hidden, a silent pride. A pride of having been a trustworthy doctor in the middle of the night. A pride of having brought relief to an emotionally drained out mother by advicing her timely. An immense satisfaction of having been a ray of hope, a source of relief to someone's pain. The smile on their faces and the gratitude in their words, is something which cannot be traded for anything. Be it friends or otherwise, my Hippocratic oath reminds me that I will be available for all those patients who seek my help, anytime, anywhere. Which I presume means, even over phone or What's App. And so, here I come, all set to face a dozen other untimely calls, to comfort the mothers and cure their little ones. Being their true friend indeed!

AM Mridula Department of Pediatrics, ESICMC \& PGIMSR, Rajajinagar, Bangalore, India. mridu_doc@yahoo.com 